\title{
Pengaruh Penerapan Model Pembelajaran Project Based Learning Terhadap Kreativitas Siswa Pada Materi Energi Terbarukan
}

\author{
Haza Kurnia Dinantika*, Eko Suyanto, dan I Dewa Putu Nyeneng \\ Fakultas Keguruan dan IImu Pendidikan, Universitas Lampung \\ *E-mail: haza_kurnia@yahoo.com
}

\begin{abstract}
Abstrak
Penelitian ini bertujuan untuk mengetahui pengaruh penerapan model pembelajaran Project Based Learning terhadap kreativitas siswa pada materi energi terbarukan: Turbin Axis Horizontal dan Kincir Air. Populasi pada penelitian ini yaitu seluruh siswa kelas XII IPA SMA AI-Kautsar Bandar Lampung, dengan sampel kelas XII IPA sebagai kelas eksperimen dan XII IPA 7 sebagai kelas kontrol. Desain penelitian yaitu Posttest Only Control Group Design. Hasil penelitian diuji menggunakan Independent Sample T-Test dan Effect Size. Hasil penelitian yaitu kelas kontrol dengan model pembelajaran konvensional memiliki nilai rata-rata kreativitas sebesar $42 \%$ dengan kategori kurang kreatif, sedangkan kelas eksperimen dengan model pembelajaran Project Based Learning memiliki nilai rata-rata kreativitas sebesar $72 \%$ dengan kategori kreatif. Hasil uji Effect Size diperoleh nilai cohen's $d$ sebesar 3,40 dan nilai effect size $r$ sebesar 0,86 dengan kategori tinggi. Kesimpulannya yaitu terdapat pengaruh penerapan model pembelajaran Project Based Learning terhadap kreativitas siswa pada materi energi terbarukan.
\end{abstract}

Kata kunci: Project Based Learning, Kreativitas Siswa, Energi Terbarukan.

\section{PENDAHULUAN}

Pembelajaran pada abad ke-21 menuntut berbagai keterampilan yang diwajibkan untuk dikuasai oleh siswa, sehingga diharapkan pendidikan saat ini dapat menjadikan siswa agar menguasai berbagai keterampilan. Keterampilan-keterampilan yang dikatakan penting pada abad ke-21 masih berhubungan dengan empat pilar kehidupan yaitu learning to know yaitu mengetahui penguasaan materi, learning to do yaitu siswa harus belajar berkarya, learning to be yaitu siswa yang mempunyai kompetensi kognitif yang mendasar termasuk kedalam pribadi yang berkualitas dan beridentitas, dan learning to live together yaitu belajar dengan kelompok akan memberikan kesempatan untuk siswa agar aktif dalam diskusi dengan kelompoknya, senantiasa memantau strategi serta pencapaian belajar dan menjadi pemikir yang kritis (Scott, 2015).

US-based Partnership untuk keterampilan pada abad ke-21, mengemukakan kompetensi yang sangat diperlukan yaitu komunikasi, kolaborasi, berpikir kritis, dan kreativitas. Assessment and Teaching of 21 st Century Skills mengkategorikan keterampilan pada abad ke-21 dalam 4 kategori, yaitu cara berpikir, cara bekerja, langkah-langkah untuk bekerja, dan keterampilan apa yang digunakan di dunia (Griffin, McGaw \& Care, 2012). Cara berpikir mencakup inovasi, berpikir kritis, kreativitas, pemecahan masalah, dan membuat sebuah keputusan. Cara bekerja mencakup keterampilan dalam berkomunikasi, berkolaborasi, dan mengatur kerjasama dalam kelompok. Langkah-langkah untuk bekerja termasuk kesadaran sebagai warga negara lokal maupun global, pengembangan karir dan hidupnya, dan menanamkan rasa tanggung jawab sebagai pribadi maupun sosial, sedangkan keterampilan untuk hidup di dunia termasuk keterampilan yang mendasarkan pada literasi informasi, penguasaan teknologi informasi dan komunikasi baru, dan kemampuan untuk belajar serta bekerja melalui jaringan sosial digital.

Pada hakekatnya, fisika merupakan kumpulan pengetahuan, cara berfikir, dan penyelidikan (eksperimen). Penerapannya dalam pembelajaran harus mempertimbangkan model pembelajaran yang bagus dan efektif agar mampu membuat siswa tertarik dan termotivasi untuk mempelajari fisika. Salah satu kegiatan pembelajaran fisika yang efektif dan benar-benar mencerminkan hakekat fisika itu sendiri adalah melalui kegiatan praktik. Secara umum kegiatan praktik merupakan unjuk kerja yang 
ditampilkan guru atau siswa dalam bentuk demontrasi maupun percobaan oleh siswa tersebut melalui eksperimen atau proyek. Kegiatan praktik memiliki peran yang sangat penting dalam pembelajaran fisika karena praktik memberikan peluang kepada siswa untuk kreatif dalam melakukan inovasi, atau mendapatkan pengetahuan tentang langkah-langkah yang dilakukan ilmuwan dalam menemukan hukum fisika. Kegiatan praktik dapat terlaksana secara baik dan benar jika didukung oleh penggunaan model pembelajaran, sarana dan prasarana yang tepat. Model pembelajaran tersebut yang bisa menunjang adalah model pembelajaran Project Based Learning. Model pembelajaran Project Based Learning yaitu model pembelajaran yang relevan untuk mengimplementasikan kurikulum 2013 dan dapat mengatasi masalah secara efektif di dalam kelas (Fikriyah, 2015).

Model pembelajaran Project Based Learning yaitu model pembelajaran yang mempunyai sifat kontekstual karena model tersebut diharapkan dapat merubah gaya belajar siswa secara lebih individual dengan menaikkan motivasi belajar, serta kreativitas siswa dalam berkarya, memunculkan ide-ide kreatif serta melatih berpikir kritis, dalam menyikapi suatu masalah yang dihadapi di dunia nyata. Model pembelajaran Project Based Learning melibatkan beberapa aspek lingkungan tempat siswa berada dan belajar dengan melibatkan kreativitas yang ada dalam diri siswa (Widiyatmoko dan Pamelasari, 2012). Model pembelajaran Project Based Learning dapat melibatkan siswa secara aktif dalam membangun pengetahuannya sendiri serta melibatkan kerja kelompok agar menghasilkan suatu proyek sebagai aplikasi prinsip atau konsep yang telah diperoleh. Pembelajaran menggunakan model ini membuat siswa terbiasa menemukan sendiri konsep fisika melalui proyek yang diberikan dengan mengkontruksi pengetahuan dalam diri siswa (Sari, Sutikno, \& Masturi, 2015).

Model Pembelajaran Project Based Learning dapat memberikan peluang kepada siswa untuk menggali materi dengan menggunakan berbagai cara. Siswa diberi kesempatan untuk mempelajari materi dengan berbagai cara, terlibat dalam pemecahan masalah, dan terlibat dalam kegiatan perancangan produk diharapkan keterampilan dan pemahaman siswa dapat lebih berkembang sehingga siswa lebih memahami materi yang dipelajari. Model ini memiliki perbedaan dengan model konvensional yang banyak digunakan selama ini. Pada model pembelajaran Project Based Learning, guru memiliki peran yaitu fasilitator bagi siswa agar mendapatkan jawaban dari pertanyaan penuntun, sedangkan pada kelas konvensional guru memiliki peran yang menguasai keseluruhan materi dan semua informasi diberikan secara langsung kepada siswa. Pada kelas dengan model pembelajaran Project Based Learning, siswa akan dibiasakan bekerja sama secara kolaboratif, penilaian dilakukan secara autentik, dan sumber belajar dapat sangat berkembang, karena hal tersebut maka model pembelajaran Project Based Learning berbeda dengan kelas konvensional yang sudah terbiasa dengan situasi kelas individual, penilaian yang dilakukan dominan pada aspek hasil dari pada proses (Dewi, 2017).

Model pembelajaran Project based learning memiliki beberapa kelemahan diantaranya yaitu biaya yang tidak murah. Solusi lain yang dapat digunakan agar mengatasi kekurangan tersebut yaitu dengan menggunakan bahan bekas. Keuntungan dengan menggunakan bahan bekas sebagai pemecahan masalah yaitu bahan tersebut mudah diperoleh dari lingkungan sekitar (Kurniawati, 2017), dan memanfaatkan bahan bekas pakai yang terdapat di lingkungan juga dapat dimaksimalkan.

Penelitian yang dilakukan oleh Alawiyah (2015) menunjukkan bahwa pemanfaatan bahan bekas juga dapat menunjang sikap ilmiah dan meningkatkan kreativitas siswa. Kreativitas merupakan salah satu indikator berpikir tingkat tinggi. Berpikir kritis dan berpikir kreatif digunakan untuk memecahkan permasalahan yang ada. Kreativitas menurut Slameto (2016) merupakan kemampuan untuk menghasilkan hal yang berbeda dan tidak dapat dibuat oleh orang lain. Sesuatu yang dihasilkan ini merupakan suatu hal atau benda yang baru yang tentunya memiliki daya guna. Kreativitas merupakan suatu proses mental yang mana proses ini mengarah pada kemampuan untuk berpikir orisinal dibandingkan dengan orang lain. Kreativitas itu sendiri merupakan pengalaman yang digunakan untuk mengekspresikan diri, baik dengan diri sendiri maupun dengan orang lain secara asli yang mana dengan pengalaman tersebut dapat mendapatkan ide, gagasan, dan langkah-langkah yang berbeda yang tentunya suatu hal yang memiliki nilai guna. 
Haza Kurnia Dinantika, Eko Suyanto, dan I Dewa Putu Nyeneng

Kreativitas sebagai salah satu kemampuan yang dibutuhkan oleh siswa dalam membantu memecahkan permasalahan dan menemukan konsep baru. Kreativitas sebagai kemampuan berpikir divergen atau cara memecahkan suatu permasalahan dengan menggunakan berbagai macam alternatif jawaban terhadap persoalan yang sama benarnya. Kreativitas siswa sebagai suatu kemampuan siswa untuk menghasilkan berbagai macam ide melalui proses berpikir yang luas dan beragam. Penanaman kebiasaan untuk berpikir kreatif perlu diterapkan melalui proses pembelajaran khususnya dalam pembelajaran Fisika (Titu, 2015). Berdasarkan Sopan (2015) mengemukakan ada 4 indikator Kreativitas siswa yaitu Kelancaran (Fluency) atau kemampuan untuk mengemukakan banyak Gagasan. Keluwesan (Flexibility), adalah kemampuan untuk mengemukakan bermacam-macam pemecahan atau pendekatan terhadap masalah. Originalitas (Originality), adalah kemampuan untuk mencetuskan gagasan dengan cara-cara yang asli, tidak klise. Elaborasi (Elaboration), adalah kemampuan untuk menguraikan sesuatu secara terinci. Hasil dari studi kasus pada penelitian ini akan digunakan 3 indikator kreativitas yaitu Kelancaran (Fluency), Keluwesan (Flexibility), dan Originalitas (Originality).

Berdasarkan Penelitian Novita, Darmawijoyo, \& Aisyah (2016) yang menerapkan pembelajaran Project Based Learning, media atau alat peraga untuk mendukung pembelajaran fisika masih sangat minim sehingga perlu adanya ide dan inovasi untuk menciptakan media yang dapat digunakan sebagai sarana belajar. Berdasarkan hal tersebut, peneliti melakukan penelitian untuk melihat bagaimana pengaruh penerapan model pembelajaran Project Based Learning terhadap kreativitas siswa pada materi Energi Terbarukan. Peneliti beranggapan bahwa penerapan model pembelajaran Project Based Learning cocok diterapkan pada materi Energi Terbarukan, karena di sekolah pokok bahasan ini baru dan belum dibelajarkan.

\section{METODE/EKSPERIMEN}

Penelitian ini dilaksanakan di SMA Al-Kautsar Bandar Lampung, dengan alamat sekolah Jl. Soekarno Hatta, Rajabasa, Kota Bandar Lampung. Waktu penelitian dilaksanakan pada semester II Tahun Ajaran 2018/2019. Populasi pada penelitian ini yaitu seluruh siswa kelas XII IPA SMA AI-Kautsar Bandar Lampung pada semester II Tahun Ajaran 2018/2019 yang berjumlah 7 kelas. Sampel penelitian menggunakan dua kelas, yaitu satu kelas sebagai kelas eksperimen dan satu kelas lainnya sebagai kelas kontrol. Sampel yang diambil digunakan teknik purposive sampling pada kelas yang memiliki nilai yang relatif sama dilihat dari nilai ulangan harian sebelum materi sumber daya energi sehingga terpilih satu kelas eksperimen dan satu kelas kontrol pada kelas XII IPA ${ }_{5}$ dan $\mathrm{IPA}_{7}$. Penelitian ini terdiri dari dua variabel penelitian, yaitu variabel bebas dan variabel terikat. Variabel bebas dalam penelitian ini yaitu penerapan model pembelajaran yaitu Project Based Learning. Variabel terikatnya adalah kreativitas siswa. Penelitian yang dilakukan merupakan penelitian eksperimen semu (Quasi Experiment) dengan menggunakan posttest only control group design. Adapun garis besar pelaksanaan penelitian dengan menggunakan desain ini digambarkan dalam Tabel 1.

Tabel 1. Posttest Only Control Group Design

\begin{tabular}{ccc}
\hline Kelas & Perlakuan & Tes Akhir \\
\hline Eksperimen & $\mathrm{X}_{1}$ & $\mathrm{O}_{1}$ \\
kontrol & $\mathrm{X}_{2}$ & $\mathrm{O}_{2}$ \\
\hline
\end{tabular}

\section{Prosedur Pelaksanaan Penelitian}

Langkah-langkah yang dilakukan pada penelitian dibagi menjadi tiga tahapan, yaitu Tahap Persiapan, Peneliti mengurus perizinan, observasi, dan menentukan kelas yang akan digunakan sebagai sampel penelitian yang akan dilaksanakan di SMA AI- Kautsar Bandar Lampung, peneliti menyusun RPP dan instrumen yang akan digunakan dalam proses pelaksanaan penelitian. Tahap Pelaksanaan, Peneliti terlebih dahulu memberikan stimulus kepada siswa, peneliti memberikan perlakuan berupa pembelajaran dengan model pembelajaran Project Based Learning pada kelas 
eksperimen dan memberikan model pembelajaran konvensional di kelas kontrol, peneliti akan memberikan tes akhir kepada siswa pada kelas eksperimen dan kelas kontrol untuk melihat kreativitas siswa tersebut. Tahap Akhir, Peneliti mengumpulkan data hasil tes kreativitas siswa dari kelas eksperimen dan kelas kontrol, Mengolah data serta menganalisis data yang diperoleh dari kelas eksperimen dan kelas kontrol, Membuat kesimpulan dan kemudian menyusun laporan penelitian.

\section{Intrumen dan Teknik Pengumpulan Data Penelitian}

Instrumen penelitian yang digunakan dalam penelitian ini, yaitu RPP dengan model pembelajaran Project Based Learning digunakan sebagai acuan guru pada pelaksanaan pembelajaran yang digunakan selama proses pembelajaran dan soal tes akhir yang digunakan berupa soal uraian berjumlah 10 soal. Tes ini digunakan untuk mengukur tingkat kreativitas siswa terhadap materi Energi Terbarukan yang diberikan saat pelaksanaan tes akhir. Sebelum digunakannya instrumen dalam sampel, instrumen diuji terlebih dahulu menggunakan uji validitas dan uji reliabilitasnya dengan pengujian validitas instrumen bantuan program SPSS. Pengumpulan data dilakukan setelah kegiatan pembelajaran dilaksanakan. Data yang diperoleh dalam penelitian ini yaitu data nilai kreativitas siswa sesudah pembelajaran. Data yang diperoleh kemudian dianalisis dengan melakukan (1) uji normalitas, (2) uji homogenitas, (3) Independent Sample T Test, (4) Effect Size.

\section{HASIL DAN PEMBAHASAN}

\section{Hasil}

Hasil penelitian yaitu kelas kontrol dengan model pembelajaran konvensional memiliki nilai ratarata kreativitas sebesar $42 \%$ dengan kategori kurang kreatif, sedangkan kelas eksperimen dengan model pembelajaran Project Based Learning memiliki nilai rata-rata kreativitas sebesar $72 \%$ dengan kategori kreatif. Hasil uji Effect Size diperoleh nilai cohen's d sebesar 3,40 dan nilai effect size rsebesar 0,86 dengan kategori tinggi, artinya penerapan model pembelajaran Project Based Learning sangat berpengaruh terhadap kreativitas siswa.

\section{Data Hasil Uji Keseluruhan}

Data nilai rata-rata kreativitas siswa dapat dilihat pada tabel 2.

Tabel 2. Nilai Rata-rata Kreativitas Siswa

\begin{tabular}{ccc}
\hline Kelas & Nilai Rata-rata & Keterangan \\
\hline Esperimen & $72 \%$ & Kreatif \\
Kontrol & $42 \%$ & Kurang Kreatif \\
\hline
\end{tabular}

Data uji normalitas dan homogenitas dapat dilihat pada tabel 3.

Tabel 3. Uji Normalitas dan Homogenitas

\begin{tabular}{ccc}
\hline Variabel & Normalitas & Homogenitas \\
Penelitian & & \\
\hline Tes Akhir & $\checkmark$ & $\checkmark$ \\
\hline
\end{tabular}

Dari Tabel 3 maka disimpulkan bahwa data nilai kreativitas berdistribusi normal dan homogen.

Data hasil uji independent sampel $t$-test nilai kreativitas dapat dilihat pada tabel 4 .

Tabel 4. Hasil Uji Independent Sample T-Test Nilai Kreativitas

\begin{tabular}{ccc}
\hline $\begin{array}{c}\text { Variabel } \\
\text { Penelitian }\end{array}$ & Asymp Sig & Keterangan \\
\hline Tes Akhir & 0,000 & Ada Perbedaan \\
\hline
\end{tabular}

Berdasarkan Tabel 3 dapat diketahui nilai Asymp Sig (2-tailed) pada uji hipotesis sebesar 0,000, yaitu kurang dari 0,05 maka kesimpulannya yaitu $\mathrm{H}_{0}$ ditolak dan $\mathrm{H}_{1}$ diterima, sehingga kesimpulannya bahwa terdapat pengaruh penerapan model pembelajaran berbasis proyek (Project Based Learning) terhadap 
Haza Kurnia Dinantika, Eko Suyanto, dan I Dewa Putu Nyeneng

kreativitas siswa pada materi energi terbarukan.

Data hasil uji effect size dapat dilihat pada tabel 5.

Tabel 5. Hasil Uji Effect Size

\begin{tabular}{cc}
\hline Uji & Nilai \\
\hline Cohen's $d$ & 3,40 \\
Effect size $r$ & 0,86 \\
\hline
\end{tabular}

Hasil nilai Cohen's $d$ yang diperoleh sebesar 3,40 dan hasil nilai effect size $r$ yang diperoleh dari perhitungan, yaitu 0,86 dengan kriteria tinggi, sehingga kesimpulan yang diperoleh yaitu penerapan model pembelajaran Project Based Learning yang digunakan pada penelitian ini berpengaruh tinggi terhadap kreativitas siswa pada materi energi terbarukan.

\section{Pembahasan}

Penelitian ini dilakukan untuk melihat pengaruh model pembelajaran berbasis proyek (Project Based Learning) terhadap kreativitas siswa pada materi energi terbarukan dengan cara memberikan soal tes akhir. Pemberian soal tes akhir dilakukan untuk mengukur kreativitas siswa setelah diberikan perlakuan. Penelitian ini menggunakan dua kelas, yaitu kelas eksperimen menggunakan model pembelajaran Project Based Learning dan kelas kontrol menggunakan model pembelajaran Konvensional.

Setelah dilakukan uji hipotesis (independent sample t-test) diperoleh nilai asymp sig. (2-tailed) sebesar 0,000 . Hasil ini menunjukkan bahwa terdapat perbedaan nilai rata-rata tes pada kelas eksperimen yang menerapkan model pembelajaran Project Based Learning dengan kelas kontrol yang menggunakan model pembelajaran konvensional. Kelas eksperimen yang menerapkan model pembelajaran Project Based Learning memiliki nilai rata-rata tes kreativitas siswa lebih besar dibandingkan dengan kelas kontrol yang menerapkan model pembelajaran konvensional, sehingga dapat dikatakan terdapat pengaruh penerapan model pembelajaran berbasis proyek (Project Based Learning) terhadap kreativitas siswa pada materi energi terbarukan.

Kelas eksperimen lebih baik dalam kreativitasnya dibandingkan dengan kelas kontrol, karena pada proses dan kegiatan pembelajaran dengan menerapkan model pembelajaran Project Based learning terdapat sintaks pembelajaran yang memacu siswa untuk lebih kreatif dalam pembelajaran, seperti siswa juga diberikan kesempatan untuk menghasilkan berbagai ide melalui proses berpikir yang luas dan beragam serta guru berperan sebagai fasilisator dan mengarahkan siswa yang dapat menanamkan kebiasaan berpikir kreatif. Siswa dapat menghasilkan banyak rumusan tema proyek, mengemukakan langkah-langkah penyelesaian proyek, mengemukakan macam-macam pemecahan masalah, dapat mencetuskan gagasan dengan cara yang asli dan tidak meniru orang lain.

Hasil Penelitian didukung oleh Surya, Relmasira, \& Hardini (2018) menunjukkan bahwa penerapan model pembelajaran Project Based learning menuntut siswa untuk berpikir kreatif. Hal ini ditunjukkan dengan siswa banyak yang bertanya, mengemukakan pendapat, dan menjawab pertanyaan guru. Dalam pembelajaran Project Based learning, siswa tidak hanya dituntut untuk mengungkapkan gagasannya, namun siswa juga dituntut untuk memecahkan masalah melalui pemberian proyek sehingga kreativitas siswa dalam berpikir meningkat. Menurut Subagia, dkk (2014) juga menyatakan bahwa pada pembelajaran Project Based learning siswa harus merancang, memecahkan masalah, membuat keputusan, melakukan kegiatan investigasi, dan bekerja secara mandiri bersama kelompoknya, dan siswa dengan antusias yang tinggi akan melaksanakan tahapantahapan pembelajaran Project Based learning dengan baik sehingga berdampak pada pencapaian yang optimal. Menurut (Cawi, dkk 2014) menambahkan bahwa model pembelajaran Project Based Learning dapat menstimulasi motivasi, proses, dan meningkatkan kreativitas siswa menggunakan masalah apa saja yang berkaitan dengan materi tertentu pada situasi nyata. Hal serupa juga telah dibahas di pendahuluan, bahwa model pembelajaran Project Based Learning dapat melibatkan siswa 
secara aktif dalam membangun pengetahuannya sendiri serta melibatkan kerja kelompok untuk menghasilkan suatu proyek. Pembelajaran menggunakan model ini membuat siswa terbiasa menemukan sendiri konsep fisika melalui proyek yang diberikan dengan mengkontruksi pengetahuan dalam diri siswa (Sari, dkk., 2015).

Kelas kontrol memiliki kreativitas yang lebih rendah, karena penerapan model pembelajaran konvensional hanya menggunakan metode ceramah, guru sebagai pemberi informasi utama tanpa memberikan kesempatan untuk siswanya agar mengembangkan pengetahuannya dan mengemukakan ide serta pemecahan terhadap masalah. Pernyataan ini didukung oleh (Triani, 2015) yang menyatakan bahwa kekurangan model pembelajaran konvensional, yaitu sebagian siswa kurang paham menerima materi yang dijelaskan oleh guru dan siswa tidak bisa mencatat materi dengan baik, karena siswa bosan, kurang berpartisipasi dalam kegiatan pembelajaran, karena peran guru sebagai sumber belajar siswa sehingga keadaan kelas menjadi monoton.

Hasil perhitungan nilai rata-rata tes kreativitas siswa pada kelas eksperimen dan kelas kontrol memiliki perbedaan yang cukup jauh, dapat dilihat pada Gambar 1.

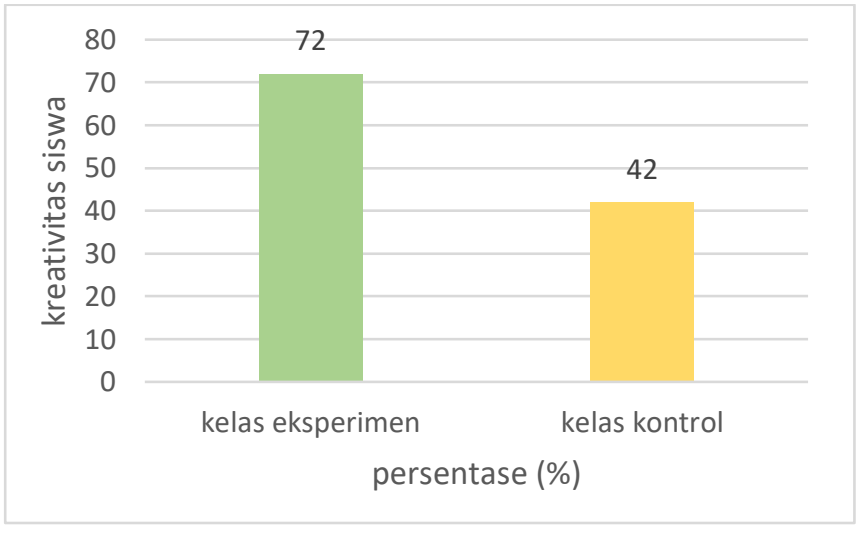

Gambar 1. Grafik Perbedaan Nilai Rata-rata Kreativitas Siswa

Kelas eksperimen mendapatkan nilai rata-rata kreativitas $72 \%$ dan kelas kontrol mendapatkan rata-rata $42 \%$. Kelas eksperimen masuk kategori kreatif dan kelas kontrol masuk kategori kurang kreatif. Dari hasil nilai rata-rata kreativitas tersebut, maka kesimpulannya yaitu kelas yang menggunakan model pembelajaran Project Based Learning lebih dapat meningkatkan kreativitas siswa dalam mengemukakan gagasan, mengemukakan pemecahan terhadap masalah, dan dapat mengemukakan gagasan dengan cara sendiri tanpa melihat karya orang lain dibandingkan dengan kelas yang menggunakan model pembelajaran konvensional yang hanya berpusat kepada guru. Hal ini serupa dengan penelitian Maula (2014) yang menyatakan bahwa penerapan model pembelajaran Project Based Learning sangan berpengaruh terhadap kreativitas siswa dibandingkan dengan model pembelajaran konvensional. Dewi (2017) juga menambahkan bahwa perbedaan model pembelajaran konvensional dan model pembelajaran Project Based Learning, yaitu pada model pembelajaran konvensional menghafal materi saja tanpa memikirkan bagaimana faktanya, berusaha dengan sendirinya agar mencapai target, siswa bergantung kepada guru, guru sebagai pemberi informasi. Sedangkan pada model pembelajaran Project Based Learning, siswa menginvestigasi dan menyimak isu yang ada pada dunia nyata, siswa bekerja sama dalam tim untuk mencapai target, tidak bergantung kepada guru sebagai pusat informasi, dan guru yaitu sebagai fasilitator dan menyediakan sumber daya. Hal inilah yang memungkinkan terdapat perbedaan nilai rata-rata tes yang diperoleh kelas eksperimen dan kelas kontrol.

Besarnya nilai Cohen's $d$ yang diperoleh sebesar 3,40 dan hasil nilai effect size $r$ yang diperoleh dari perhitungan, yaitu 0,86 dengan kriteria tinggi, menunjukkan bahwa model pembelajaran Project Based Learning berpengaruh tinggi dalam penelitian ini, sejalan dengan penelitian yang dilakukan Sugiarti (2017) menyatakan bahwa pembelajaran model Project Based Learning efektif untuk 
Haza Kurnia Dinantika, Eko Suyanto, dan I Dewa Putu Nyeneng

meningkatkan kreativitas siswa terbukti dengan adanya peningkatan persentase pada setiap siklusnya. Hal ini juga didukung oleh Widyastuti (2016) bahwa model pembelajaran Project Based Learning merupakan salah satu cara guru untuk menjadikan siswa aktif dan lebih memahami materi-materi pembelajaran, sehingga nilai effect size yang diperoleh juga tinggi. Hasil nilai effect size pada penelitian ini diperoleh dari perhitungan nilai rata-rata kreativitas kelas eksperimen, yaitu $72 \%$ dan nilai rata-rata kreativitas kelas kontrol $42 \%$ dengan menggunakan kalkulator cohen's $d$ dan hasil yang diperoleh tinggi. Hal ini dikarenakan model pembelajaran Project Based Learning dengan sintaks yang sudah baik dalam memacu kreativitas siswa. Sebagaimana hasil uji hipotesis dan beberapa hasil penelitian yang berhubungan serta teori yang mendukung, maka rumusan masalah dalam penelitian ini dapat ditemukan jawabannya, yaitu penerapan model pembelajaran Project Based Learning berpengaruh sangat baik dalam meningkatkan kreativitas siswa pada materi energi terbarukan.

\section{PENUTUP}

Terdapat pengaruh penerapan model pembelajaran Project Based Learning terhadap kreativitas siswa pada materi energi terbarukan: turbin angin axis horizontal dan kincir air, dibuktikan dengan terdapat perbedaan nilai rata-rata kreativitas antara kelas eksperimen dan kelas kontrol. Kelas eksperimen termasuk ke dalam kategori kreatif, sedangkan kelas kontrol termasuk ke dalam kategori kurang kreatif, dengan nilai signifikansi sebesar 0,000. Besarnya pengaruh model pembelajaran Project Based Learning masuk ke dalam kriteria besar, dengan nilai Cohen's $d$ sebesar 3,40 dan nilai effect size $r$ sebesar 0,86 .

Saran untuk peneliti lain yang akan menggunakan model Project Based Learning diharapkan dapat mengatur waktu dengan baik karena dalam menerapkan model pembelajaran Project Based Learning seluruh sintaks dapat diterapkan dengan sekurang-kurangnya dua kali pertemuan, serta memikirkan penentuan tema proyek yang akan digunakan ketika penelitian. Saran bagi guru yang akan menerapkan model pembelajaran Project Based Learning diharapkan menguasai sintaks pembelajaran dengan baik agar pembelajaran menjadi efektif dan efisien.

\section{DAFTAR PUSTAKA}

Alawiyah, M., Sudarti, \& Prihandono. (2015). Pengaruh model pembelajaran project based learning berbasis pemanfaatan bahan bekas terhadap sikap ilmiah dan hasil belajar mata pelajaran IPA di MTs Jenggawah. Jurnal Education, 2(1), 37-40.

Cawi, I., Marhaeni., Gede, R. (2014). Pengaruh pembelajaran berbasis proyek terhadap hasil belajar menggambar layout dengan kovariabel kecerdasan spasial dan kecerdasan logis Matematis. Jurnal Universitas Pendidikan Ganesha Singaraja, 4(1), 21-25.

Dewi, R. (2017). Penerapan model pembelajaran project based learning untuk meningkatkan hasil belajar fisika dan keterampilan proses sains peserta didik kelas X SMA N Banguntapan. Jurnal Fakultas Matematika dan IImu Pengetahuan Alam Universitas Negeri Yogyakarta, 2(1), 5-10.

Fikriyah. (2015). Model pembelajaran berbasis proyek (project based learning) disertai media audio-visual dalam pembelajaran fisika di SMAN 4 Jember. Jurnal Pembelajaran Fisika, 4(2), 181-186.

Griffin, P., McGaw, B. \& Care, E. (2012). Assessment and Teaching of 21st Century Skills. Springer, New York.

Kurniawati. (2017). Pembelajaran SAINS bermuatan karakter ilmiah dengan alat peraga barang bekas dan assesmen kerja. Jurnal Pendidikan Indonesia, 6(1), 49-59. http://dx.doi.org/10.23887/jpiundiksha.v6i1.8866 
Maula. (2014). Pengaruh PjBL (project based learning) terhadap kemampuan berpikir kreatif dan hasil belajar siswa pada materi pengelolaan lingkungan. Jurnal Universitas jawa barat, 3(2), 12-16.

Novita, D., Darmawijoyo, D., \& Aisyah, N. (2016). Pengembangan LKS berbasis Project Based Learning untuk pembelajaran materi segitiga di kelas VII. Jurnal Pendidikan Matematika, 10(2), 1-12.. http://dx.doi.org/10.22342/jpm.10.2.3626.1-12

Surya, A. P., Relmasira, S. C., \& Hardini, A. T. A. (2018). Penerapan Model Pembelajaran Project Based Learning (Pjbl) Untuk Meningkatkan Hasil Belajar Dan Kreatifitas Siswa Kelas lii Sd Negeri Sidorejo Lor 01 Salatiga. Jurnal Pesona Dasar, 6(1), 41-54.

Sari, D. N., Sutikno, S., \& Masturi, M. (2015). Pengaruh pembelajaran berbasis proyek terhadap kreativitas siswa melalui elektroskop sederhana. Prosiding Seminar Nasional Fisika (E-Journal) , 4(1),19-24.

Scott, C.L. (2015). The Futures of Learning 2: What kind of learning for the 21st century?. Jurnal Unesco Education Research and Foresight, 14(2), 2-7.

Slameto. (2016). Peningkatan hasil belajar matematika melalui metode pembelajaran make a match berbantu media gambar siswa sekolah dasar. Jurnal Pendidikan Dasar, 4(2), 2-5.

Sopan, D. (2015). Upaya peningkatan kreativitas siswa pada mata pelajaran muatan lokal batik menggunakan metode Project based learning pada siswa Kelas VIII G SMPN 1 Trucuk Kab. Klaten. Jurnal Universitas Negeri Yogyakarta, 4(2), 18-21.

Subagia,. \& I Wayan. (2014). Pengaruh model pembelajaran berbasis proyek terhadap hasil belajar IPA ditinjau dari self efficacy siswa. Jurnal Program Pascasarjana Universitas Pendidikan Ganesha, 6(1), 8-15.

Sugiarti, A. (2017). Penerapan model project based learning untuk meningkatkan kreativitas dan hasil belajar siswa kelas IV pada sub tema keberagaman budaya bangsaku. Jurnal Universitas Negeri Pasundan Bandung, 3(2), 15-24.

Titu, M. (2015). Penerapan model pembelajaran project based learning (PjBL) untuk meningkatkan kreativitas siswa pada materi konsep masalah ekonomi. Jurnal refleksi Edukatika, 6(1), 177-178.

Triani, W. (2015). Pengaruh model pembelajaran project based learning terhadap hasil belajar geografi. Jurnal Fakultas Keguruan dan IImu Pendidikan Universitas Lampung, 2(1), 8-9.

Widiyatmoko, A., \& S. D. Pamelasari. (2012). Pembelajaran berbasis proyek untuk mengembangkan alat peraga IPA dengan memanfaatkan bahan bekas pakai. Jurnal Pendidikan IPA Indonesia, 1(1), 51-56.

Widyastuti, I. (2016). Pengaruh model project based learning terhadap hasil belajar pendidikan kewarganegaraan di kelas IV SD. Jurnal Pendidikan Dasar Universitas Tanjungpura Pontianak. 3(1): 3-5. 